\title{
ANALISIS STRATEGI PT. BPR BUMI PRIMA DANA DALAM MEMINIMALISIR KREDIT MACET DI MASA PANDEMI COVID-I9
}

\section{STRATEGY ANALYSIS PT. BPR BUMI PRIMA DANA IN MINIMIZINGDURING LOSS OF LOANSTHE COVID-I 9 PANDEMIC}

\section{Ni Putu Mita Adnyani ${ }^{\text {* }}$ \\ Anak Agung Istri Agung Maheswari,S.ST.,M.Par. ${ }^{2}$}

\author{
*IUnivesitas Pendidikan Nasional, \\ Denpasar, Bali, Indonesia \\ 2Univesitas Pendidikan Nasional, \\ Denpasar, Bali, Indonesia \\ email: mitaadnyani8I@gmail.com \\ agungmaheswari@undiknas.ac.id
}

\begin{abstract}
Abstrak
Kredit macet terjadi ketika nasabah tidak mampu memenuhi kewajibannya untuk membayar angsuran kredit. Nasabah mengalami ketidakcukupan dana lantaran terdampak pandemi covid-19 yang mengharuskan suatu perusahaan untuk mengeluarkan kebijakan PHK supaya mengurangi kerugian dimasa pandemi covid-19. Sehingga pada kondisi pandemi covid-19 saat ini perbankan akan rentan mengalami resiko kredit macet. Laporan ini bertujuan untuk mengetahui bagaimana analisa strategi PT. BPR Bumi Prima Dana dalam meminimalisir kredit macet dimasa pandemi covid-19. Perbankan wajib menerapkan strategi untuk meminimalisir kredit macet yang terjadi sehingga mampu mengurangi dampak kerugian dimasa pandemi. Analisis yang digunakan adalah analisis deskriptif kualitatif yaitu analisis yang menggambarkan sesuatu berdasarkan data yang sudah diperoleh dengan teknik pengumpulan data melalui wawancara yang mudah untuk dipahami dan dimengerti. Hasil penelitian disebutkan bahwa syarat - syarat pengajuan kredit masih sama dengan tahun - tahun sebelum masa pandemi covid-19 dan strategi yang dilakukan dalam meminimalisir kredit macet yaitu dengan memberikan relaksasi kepada nasabah sesuai dengan kebijakan yang dikeluarkan oleh OJK dengan mengklasifikasikan terlebih dahulu kedalam 3 kategori yaitu : ringan, sedang, berat/parah yang sesuai dengan kondisi keuangan nasabahnya. Serta rutin melakukan pemantauan dengan memberikan surat pemberitahuan kewajiban dan pengecekan secara langsung untuk mengetahui kondisi sesungguhnya yang dialami debitur.
\end{abstract}

\section{Kata Kunci:}

Kredit Macet

Strategi kredit

Penyaluran kredit

Pandemi

Covid-19

Keywords:

Bad Credit

Credit Strategy

Credit Distribution

Pandemic

Covid-19

\begin{abstract}
Bad loans occur when customers are unable to fulfill their obligations to pay credit installments. Customers experience insufficient funds because they are affected by the covid-19 pandemic which requires a company to issue a layoff policy in order to reduce losses during the covid-19 pandemic. So that in the current Covid-19 pandemic conditions, banks will be vulnerable to the risk of bad credit. This report aims to find out how the strategic analysis of PT. BPR Bumi Prima Dana in minimizing bad loans during the covid-19 pandemic. Banks are required to implement strategies to minimize bad loans that occur so as to reduce the impact of losses during the pandemic. The analysis used is descriptive qualitative analysis, namely an analysis that describes something based on data that has been obtained with data collection techniques through interviews that are easy to understand and understand. The results of the study stated that the conditions for applying for credit were still the same as in the years before the covid-19 pandemic and the strategy taken to minimize bad loans was to provide relaxation to customers in accordance with the policies issued by the OJK by first classifying them into 3 categories, namely : mild, moderate, severe/severe according to the customer's financial condition. As well as routine monitoring by providing notification letters of obligations and direct checks to find out the actual conditions experienced by debtors.
\end{abstract}




\section{PENDAHULUAN}

Perbankan merupakan suatu lembaga yang bergerak dibidang keuangan yang berkontribusi penting dalam perkembangan perekonomian suatu negara. Hal tersebut dapat dilihat jika dunia perbankan berada di kondisi yang tidak stabil maka perekonomian suatu negara pun juga tidak akan stabil. Menurut undang - undang Nomor 10 tahun 1998 yang merupakan perubahan dari undang - undang Nomor 7 tahun 1992 menyebutkan tentang pengertian perbankan, bank merupakan badan usaha yang menghimpun dana dari masyarakat dalam bentuk simpanan dan menyalurkan dalam bentuk kredit atau bentuk - bentuk lainnya dalam rangka meningkatkan taraf hidup masyarakat.

Perkembangan dunia perbankan pada saat ini mengalami perkembangan yang sangat pesat hal tersebut menyebakan lembaga keuangan perbankan berlomba - lomba untuk menyediakan berbagai produk keuangan yang dapat meningkatkan minat masyarakat dalam menggunakan layanan keuangan dari perbankan tersebut. Seperti salah satu lembaga keuangan yang berada di wilayah kabupaten Tabanan, Bali yaitu PT. BPR Bumi Prima Dana. Perusahaan ini menyediakan berbagai layanan keuangan seperti tabungan pribumi, kredit satwa, kredit primaguna, dan kredit konsumtif.

kegiatan kredit yang disediakan merupakan salah satu layanan penyaluran dana kepada masyarakat yang banyak dilakukan oleh lembaga perbankan. Karena penghasilan terbesar dalam perbankan berasal dari bunga atas penyaluran kredit tersebut, sehinga bagi badan usaha maupun individu yang membutuhkan dana tambahan dapat menggunakan layanan kredit untuk membantu memdanai usaha yang nantinya akan mereka jalankan.

Namun pada situasi saat ini seluruh dunia termasuk di Indonesia digemparkan oleh berita menyebarnya virus yang membahayakan. Virus yang berasal dari Wuhan, China ini dinamakan coronavirus Disease 2019 atau disingkat covid-19. Penyebaran virus ini berdampak negatif dalam berbagai sektor diantaranya kesehatan, pendidikan, ekonomi, dan juga sosial. Karena proses penyebaran virus yang sangat cepat yaitu dengan melalui droplet atau percikan air yang keluar lewat saluran pernapasan maka pemerintahpun menyarankan kepada masyarakatnya untuk selalu menjaga kontak fisik dengan sesama atau dikenal dengan istilah sosial distancing dan semua kegiatan sosialpun akhirnya harus dilakukan dirumah saja. Dengan adanya kebijakan yang dikeluarkan oleh pemerintah tersebut menyebabkan beberapa sektor seperti hotel, restoran, mall dan tempat pariwisata lainnyapun mengalami penurunan yang sangat drastis karena sepinya pengunjung atau pelanggan. Akiatnya banyak pekerja yang harus mengalami PHK. Kebijakan tersebut diambil agar perusahaan dapat terhindar atau mengurangi dampak kerugian dimasa pandemi. Berdasaran hasil survey yang dilakukan oleh Cbnb Indonesia sebanyak $35 \%$ pekerja terkena Pemutusan Hubungan Kerja (PHK) dan 19\% pekerja yang harus dirumahkan sementara.

Berdasarkan keputusan tersebut, sebagian besar masayarakat harus kehilangan pekerja sebagai sumber utama penghasilan mereka. Termasuk juga para debitur yang akhirnya mengalami kesulitan atau tidak dapat melaksanakan kewajiban mereka dalam membayar angsuran kredit. Sehingga kondisi ini membuat kredit yang telah diambil oleh pihak debitur mengalami masalah atau dapat disebut sebagai kredit macet. Kredit macet merupakan piutang yang tidak tertagih atau kredit yang dianggap memiliki kriteria kurang lancar, hal tersebut diragukan karena mengalami kesusahan dalam pelunasan akibat dari adanya faktor-faktor tertentu (Hermanto, 2006: 17).

Maka dari itu pihak bank harus senantiasa mempunya strategi yang diterapkan dalam pemberian kredit kepada masyarakat guna meminimalisir terjadinya kredit macet, terlebih lagi dimasa pandemi covid- 19 yang telah kita alami pada saat ini. kondisi kredit macet yang dihadapi oleh pihak bankpun tidak terlepas dari konsep 5 C yaitu Character, Capacity, Capital, Collateral dan Condition yang dimana semua konsep itu dijadikan sebagai dasar penilaian kepada debitur dalam memutuskan layak atau tidaknya untuk diberikan kredit ( Usman, 2003:247) .Berdasarkan latar belakang yang sudah dipaparkan diatas, penulis tertarik untuk melakukan studi kasus yang berjudul " Analisis Strategi PT. BPR Bumi Prima Dana dalam Meminimalisir Kredit Macet dimasa Pandemi Covid-19".

\section{METODOLOGI}

Metode yang digunakan dalam penelitian ini yaitu metode kualitatif. Yang artinya penelitian ini dilakukan untuk menggambarkan dan menjelaskan suatu fenomena, dimana hasil yang dikumpulkan bukan berdasarkan angka melainkan dari wawancara, observasi dan dokumen - dokumen yang lainnya. Sehingga data yang dihasilkan merupakan data yang sesuai dengan fakta realita yang ada.

Jenis penelitian ini merupakan penelitian kualitatif dengan sifat penelitian termasuk deskriptif analisis, yang artinya suatu penelitian 
yang memiliki tujuan untuk mendeskripsikan dan menganalisis sesuatu fenomena penelitian yang akurat. Yang berusaha memecahkan permasalah dari objek penelitian dan menggambarkan fakta sesuai dengan fenonema yang terjadi. Adapun metode pengumpulan data dalam penelitian ini yaitu: (I)Wawancara dengan Tanya jawab secara langsung dengan informan atau narasumber. Dalam penelitian ini informan atau narasumbernya yaitu kepala bagian kredit dan karyawan bagian kredit di PT. BPR Bumi Prima Dana. (2)Kepustakaan (library research) yaitu dengan mengumpulkan bahan - bahan penelitian dari berbagai sumber seperti jurnal - jurnal yang berhubungan dengan objek penelitian. (3)Observasi dengan memperhatikan fenomena fenomena dari objek penelitian secara langsung yang nantinya akan digunakan sebagai data dalam penelitian.

\section{HASIL DAN PEMBAHASAN}

\section{A. Analisis Permasalahan}

Seperti yang diketahui bersama, pada kondisi saat ini seluruh masyarakat diresahkan dengan adanya virus yang berbahaya yang dikenal dengan Coronavirus Disease 2019 atau Covid-19. Sehingga berbagai lapisan masyarakat mengalami dampak negative dari adanya penyebaran virus ini seperti hotel, restoran, mall dan tempat pariwisata lainnya dengan mengalami penurunan yang drastis akibat dari sepi pengunjung atau pelanggan. Hal ini berdampak dengan banyaknya masyarakat yang harus kehilang pekerjaannya atau dirumahkan sementara. Dengan adanya kondisi ini, menimbulkan permasalah di bidang perekonomian pada masyarakat. Termasuk juga nasabah di PT. BPR Bumi Prima Dana yang mengalami beberapa permasalahan di tengah pandemi seperti :

- Tabungan nasabah mengalami penurunan akibat dari nasabah yang banyak melakukan penarikan dimasa pandemi.

- Nasabah meminta keringan bunga dalam pengambilan kredit.

- Nasabah hanya mampu membayar bunga kredit.

- Nasabah yang tidak dapat membayar angsuran kredit (Kredit Macet) .

Berdasarkan data yang diberikan oleh pihak PT. BPR Bumi Prima Dana terdapat beberapa nasabah yang mengalami kredit macet yaitu :

\begin{tabular}{|l|l|l|}
\hline Waktu & $\begin{array}{l}\text { Total } \\
\text { nasabah yang } \\
\text { ngambil } \\
\text { kredit }\end{array}$ & $\begin{array}{l}\text { Kredit } \\
\text { Macet }\end{array}$ \\
\hline $\begin{array}{l}\text { Sebelum } \\
\text { Pandemi } \\
\text { (tahun 2019) }\end{array}$ & 297 nasabah & 3 nasabah \\
\hline Selama & 276 Nasabah & 7 nasabah \\
\hline
\end{tabular}

\author{
pandemi \\ Tabel I daftar nasabah pengambilan kredit \\ dan kredit macet
}

Dengan data diatas dapat dilihat bahwa selama pandemi jumlah nasabah yang melakukan pengambilan kredit mengalami penurunan, namun jumlah kredit macet pengalami kenaikan. Selain itu nasabah yang mengambil kredit dimasa pandemi juga mengajukan permohonan relaksasi kredit karena tidak dapat melaksanakan kewajibannya dalam membayar angsuran kredit. Dan jumlah nasabah yang mengajukan relaksasi kredit sebanyak II8 nasabah dari jumlah 276 nasabah.

\section{B. Pembahasan}

I) Bagaimana kebijakan penyaluran kredit yang dilakukan oleh PT. BPR Bumi Prima Dana untuk meminimalisir kredit macet dimasa pandemi covid-19?

Proses penyaluran kredit yang dilakukan oleh PT. BR Bumi rima Dana pada kondisi pandemi covid-19 seperti sekarang ini masih memberlakukan syarat - syarat yang sama dengan tahun - tahun sebelumnya. Adapun syarat - syarat penyaluran kredit di PT. BPR Bumi Prima Dana yaitu :

a) Kredit Prima Guna :

Suku Bunga $1.75 \%$ - 2\% menurun dengan persyaratan :

- Fotocopy KTP suami istri yang masih berlaku

- Fotocopy Kartu Keluarga (KK)

- Fotocopy NPWN*)

- Fotocopy ijin usaha *)

-Fotocopy agunan

-Asli slip gaji untuk pegawai / karyawan

- Fotocopy PBB tahun terakhir

b) Kredit konsumtif :

Kredit yang ditawarkan memiliki suku bunga tetap dengan persyaratan:

$$
\begin{aligned}
& \text { - } \quad \text { Fotocopy KTP suami istri } \\
& \text { - } \quad \text { yang masih berlaku } \\
& \text { KK) Fotocopy Kartu Keluarga ( } \\
& \text { - } \\
& \text { - } \\
& \text { Fotocopy agunan } \\
& \text { Asli slip gaji untuk pegawai / }
\end{aligned}
$$

c) Kredit satwa

Kredit yang ditawaran memiliki suku bunga tetap dengan peryaratan :

Fotocopy KTP suami istri yang masih berlaku

Fotocopy Kartu

Keluarga ( KK)

- Fotocopy agunan 


\section{-Asli slip gaji untuk pegawai / karyawan}

2) Bagaimana strategi yang dilakukan oleh PT. BPR Bumi Prima Dana untuk meminimalisir kredit macet dimasa pandemi covid-19?

Langkah - langkah yang dilakukan oleh pihak PT. BPR Bumi Prima Dana dalam meminimalisir kredit macet dimasa pandemi covid-19 yaitu dengan memberikan "RELAKSASI “ pada pembayaran kewajiban angsuran kredit. Kebijakan ini diberlakukan sesuai dengan keputusan yang dikeluarkan oleh Otoritas Jasa Keuangan (OJK) . namun sebelum kebijakan ini diberikan kepada para nasabah, pihak PT. BPR Bumi Prima Dana terlebih dahulu melakukan tahapan - tahapan berikut :

a. Langkah pertama yang dilakukan oleh pihak PT. BPR Bumi Prima Dana yaitu mengklasifikasikan nasabah debitur ke dalam 3 kategori sesuai dengan seberapa besar dampak pandemi covid19 bagi keuangan mereka. 3 kategori tersebut yaitu:

\section{- Ringan \\ - Sedang \\ - Berat / parah}

b. Setelah melakukan klasifikasi mengenai kategori tersebut, pihak PT. BPR Bumi Prima Dana akan melakukan analisis untuk mencari keputusan yang baik dan tepat serta tidak merugikan antara pihak PT. BPR Bumi Prima Dana maupun pihak debiturnya.

c. Jika pihak debitur berada dikaterori yang ringan, maka langkah penyelesaian yang diambil yaitu dengan memberikan “ RELAKSASI “ berupa penambahan jangka waktu kredit dari perjanjian awal. Hal tersebut dilakukan agar jumlah kewajiban angsuran kredit lebih sedikit dari kewajiban sebelumnya sehingga jumlah yang harus dibayarpun dapat dijangkau oleh pihak debitur. Serta dengan ketentuan menyesuaikan dari kemampuan nasabahnya.

d. Jika pihak debitur berada dikategori sedang, maka langkah penyelesaian yang dilakuan yaitu dengan memberikan "RELAKSASI", dimana pihak debitur dapat memenuhi kewajibannya hanya dengan minimal membayar bunganya saja sampai dengan batas waktu bulan
Maret 2022 yang telah disesuaikan dengan kebijakan yang dikeluarkan oleh Otoritas Jasa Keuangan (OJK), sehingga pihak debitur diberikan kemudahan untuk tidak membayar pokoknya. serta pelaksanaan kebijakan ini dilakukan evaluasi perjalanannya setiap 3 bulan sekali.

e. Untuk debitur yang berada di kategori terakhir yaitu Berat/parah ini tahapan penyelesaian yang dilakukan yaitu dengan memberikan penangguhan pembayaran kewajiban pokok beserta dengan bunga sampai dengan bulan Maret 2022 ( sesuai dengan kebijakan yang diberikan oleh OJK). Khusus untuk kategori berat / parah ini pihak PT. BPR Bumi Prima Dana melakukan perhitungan yang cermat karena sistem ini berkaitan dengan nilai agunan debitur. Proses yang dilakukan yaitu penilaian atau assessment antara nilai agunan dengan total jumlah hutang debitur pada saat masa berakhirnya penangguhan di bulan Maret 2022. Hal tersebut untuk menilai apakah nilai jaminan masih dapat mengcover atau tidak sehingga pihak PT. BPR Bumi Prima Dana perlu melakukan pemantauan yang lebih pada proses sistem ini. serta diberlakukannya evaluasi setiap 3 bulan sekali.

f. Dalam proses pemantauan yang dilakukan setiap bulannya pihak debitur diwajibkan untuk memberikan informasi berupa surat pemberitahuan kewajiban atau tunggakan kewajiban disetiap bulannya, serta sewaktu waktu pihak PT. BPR Bumi Prima Dana akan melakukan pengamatan secara langsung ke pihak debitur, pengecekan usaha ke lapangan yang dimiliki debitur agar mengetahui kondisi riil / kondisi sesungguhnya yang dialami oleh pihak debitur.

\section{KESIMPULAN}

Berdasarkan pembahasan diatas, PT. BPR Bumi Prima Dana dalam pandemi covid-19 masih menerapkan syarat - syarat pengajuan kredit yang sama dengan tahun - tahun sebelum pandemi covid-19 dan strategi yang dilakukan dalam meminimalisir kredit macet dimasa pandemi covid-19 yaitu dengan memberikan relaksasi pada pembayaran kewajiban angsuran kredit. Kebijakan ini diberikan sesuai dengan keputusan yang dikeluarkan oleh Otoritas Jasa Keuangan (OJK), yang dimana penerapannya terlebih dahulu mengklasifikasikan nasabah debitur ke dalam 3 
kategori yaitu ringan, sedang, parah/ berat sesuai dengan seberapa besar dampak yang disebabkan oleh pandemi covid-19 terhadap keuangan mereka. Serta pemantauan yang dilakukan setiap bulannya dimana pihak debitur wajib memberikan informasi surat pemberitahuan kewajiban dan sewaktu - waktu dilakukan pengecekan secara langsung untuk mengetahui kondisi riil / sesungguhnya yang dialami oleh pihak debitur.

\section{UCAPAN TERIMA KASIH}

Ucapan terima kasih yang sebesar - besarknya kepada pihak PT. BPR Bumi Prima Dana yang telah meluangkan waktunya untuk bersedia diwawancara. Serta tidak lupa penulis mengucapkan terima kasih kepada Universitas Pendidikan Nasional, melalui dosen pembimbing yang telah membimbing dengan baik sehingga penulisan jurnal ini dapat diselesaikan dengan baik pula.

\section{REFERENSI}

Bank Indonesia. 1998. UU No. 10 Tahun 1998, Tentang Perubahan Terhadap UU No. 7 tahun 1992, Jakarta.

BPR Bumi Prima Dana. Company Profile. https://bprbumiprima.com/ (diakses 7 Juli 202I)

Hermanto. 2006. Faktor-faktor Kredit Macet pada PD. BPR BKK Ungaran Kabupaten Semarang. Tugas Akhir. Fakultas Ekonomi Universitas Semarang

Putri, Cantika Adinda. 2020. Survei: Karena Covid-19, 35\% Pekerja di Indonesia Kena PHK. https://www.cnnindonesia.com/ ( diakses tanggal 7 Juli 202I )

Usaman, Rachmadi. 2003. Aspek-aspek Hukum Perbankan di Indonesia. Jakarta: Gramedia Pustaka Utama

Saraswati, R. A. (2012). Peranan Analisis Laporan Keuangan, Penilaian Prinsip 5C Calon Debitur Dan Pengawasan Kredit Terhadap Efektivitas Pemberian Kredit Pada Pd Bpr Bank Pasar Kabupaten Temanggung. Nominal, Barometer Riset Akuntansi dan Manajemen, I(I). https://doi.org//0.21831/nominal.vlil.994

Wahyuni, N. (2017). Penerapan Prinsip 5C Dalam Pemberian Kredit Sebagai Perlindungan Bank. Lex Journal: Kajian Hukum \& Keadilan, I(I). https://doi.org//0.25/39/lex.vlil.236

Rudyanti Dorotea Tobing, Hukum Perjanjian Kredit, Konsep Perjanjian Kredit Sindikasi yang Berasaskan Demokrasi Ekonomi, Laksbang Grafika, Yogjakarta, 2014.
Joko Saptono. (2008). Standar Operasional Prosedur Pengajuan Kredit dan Pengawasan Intern Untuk Mencegah Kredit Macet Pada PT Bank Tabungan Negara Cabang Malang. 